\title{
POPULAR RELIGION IN OLD TESTAMENT RESEARCH: PASt, PRESENT \& FutURE
}

\author{
Jules Gomes
}

\begin{abstract}
Summary
The heightened interest in the study of popular religion in various disciplines has led to scholars giving it consideration in the field of biblical studies. The 'popular religion movement', if one can so call recent developments, has, up to now, had no voice within traditional biblical criticism that makes little room for the 'religion of the marginalised'. Even more complex are the issues of definition, scope, and method from which scholars of popular religion struggle to extricate themselves. Nevertheless, given the cross-fertilisation with ancillary disciplines and the rise of new perspectives on scripture from different continents, such a pursuit does offer surprises that can contribute to mainstream critical thought. This paper examines the history of the 'popular religion movement' and negotiates methodological possibilities for the future.
\end{abstract}

\section{Introduction}

The study of popular religion in the past has never really been popular in biblical or non-biblical research. ${ }^{1}$ Ignored by the history-ofreligions school in biblical studies and overshadowed by the study of major comparative religions in non-biblical research, the study of popular religion is only just beginning to raise its head and find its footing. Despite the sudden flurry of publications on the topic, particularly in the non-biblical arena, ${ }^{2}$ in biblical research a

1 Jacques Berlinerblau, "The "Popular Religion" Paradigm in Old Testament Research', JSOT 60 (1993) 3-4, cites sporadic references to popular religion in Wellhausen's Prolegomena but these are anachronistic to our study and do not in any way connote popular religion as a discipline.

2 Some of the better known studies are P. Vrijhof \& J. Waardenburg, Official and Popular Religion: Analysis of a Theme for Religious Studies (The Hague: 
consensus $^{3}$ on definition, content, method, sources, ideology and nature of popular religion ${ }^{4}$ (or religions ${ }^{5}$ ) is still a long way off.

This paper intends to add to the ferment of discussion by examining why popular religion was marginalised in the past, what its present status is, and consequently where it could proceed in the future.

\section{History of Research}

Since its emergence, the study of biblical religion was almost entirely monopolised by the historical approach which proved unhelpful to the identification and development of Popular Religion as a legitimate field of exploration.

Rationalism at the end of the 18th and beginning of the 19th centuries, in a bid to free itself from dogmatics and to demonstrate that biblical religion was reasonable, tended to explain all that fell short of rational criteria as an accommodation to inferior ideas of popular thought or as a compromise to the surrounding lesser religions and cultures. This would have been sufficient reason to discard popular religion as 'superstition'.

Hegel's philosophy of history especially as understood by Vatke (1835) presupposing the dialectical progression of the 'absolute' spirit, with the union and ultimate identity of the human spirit with it would have relegated popular religion to the primitive. ${ }^{6}$ For Vatke, the introduction of Yahwism by Moses was seen as an 'antithesis' to the 'natural religion' of the people. The evolutionary approach and the division of Israelite religion into pre-prophetic, prophetic and postprophetic led to giving the prophetic period full marks, while either disparaging post-exilic Judaism (de Wette, 1813), or evaluating it

Mouton, 1979), N. Greinacher \& N. Mette, ed., Popular Religion (Edinburgh: T. \& T. Clark, 1986), M. Candelaria, Popular Religion and Liberation: The Dilemma of Liberation Theology (Albany: State University of New York Press, 1990).

3 Patrick D. Miller, 'Israelite Religion', in The Hebrew Bible and Its Modern Interpreters, ed. D. Knight and G. Tucker (Chico, CA: Scholars, 1985) 215.

4 The paper uses the singular to refer to the study of Popular Religion as a discipline.

5 One of the drawbacks in the discussion so far has been the use of the term 'popular religion' in the singular to connote a unified antithesis of official religion. But 'as historians and social-scientists have pointed out, there need not be homogeneity among the heterodox', says Berlinerblau, 'Popular Religion', 7.

6 Wilhelm Vatke, Die Religion des Alten Testaments nach den kanonischen Büchern (Berlin: G. Bethge, 1835). 
more sympathetically as a 'synthesis' (Vatke). ${ }^{7}$ This led to both the pre-classical and classical prophets being seen as the enemies par excellence of popular religion in the Old Testament. This was later revived by Smend (1893) who saw in Judaism 'to a high degree a compromise between it [prophetic religion] and popular religion, namely a compromise which suggested itself and was by no means made deliberately' ${ }^{8}$ Smend also saw Baal worship only as a 'constant negative foil' to the development of Israelite religion. For Wellhausen, the dynamics between history and religion were a result of influence exerted by 'great men'. 9 This left no room for the nobodies of popular religion. Vorländer agrees that popular religion was earlier dismissed under the influence of dialectical theology as primitive and non-Yahwistic. ${ }^{10}$

The history-of-religions school from the end of the 19th century to the First World War went beyond the narrow approaches of its predecessors and made forays into Near Eastern religions. However, these being directed towards dominant traditions in the religions of Israel's neighbours (e.g. Gunkel's use of Babylonian creation myths) ignored trajectories of popular religion.

The study of Israelite religion during the period following the Second World War continued to affirm the normative rather than the descriptive. Again, this would sideline popular religion which can hardly be regarded as 'normative' for orthodoxy. Moreover, with a Barthian view of revelation, which left little space for natural revelation, all religion, including Israelite religion was looked at with a jaundiced eye. ${ }^{11}$ Popular religion could hardly emerge as a discipline in such an atmosphere.

Strangely the 'discovery of the people' (Peter Burke's phrase) began as early as the late 18th and early 19th centuries in Europe, with philosophical undergirding from Giovanni Battista Vico (1668-

7 W.M.L. de Wette, Lehrbuch der christlichen Dogmatik, in ihrer historischen Entwicklung dargestellt (Berlin, 1813).

8 R. Smend, Lehrbuch der alttestamentlichen Religionsgeschichte (Freiburg: Mohr, ${ }^{2} 1899$ [ $\left.\left.{ }^{1} 1893\right]\right) 268$.

9 Rainer Albertz, A History of Israelite Religion in the Old Testament Period: From the Beginnings to the End of the Exile (ET John Bowden; vol. 1; London: SCM, 1994) 5.

10 Hermann Vorländer, 'Aspects of Popular Religion in the Old Testament', Concilium (1986) 63.

11 Karel van der Toorn, 'Currents in the Study of Israelite Religion', Currents in Research: Biblical Studies 6 (1998) 12. See the same article for van der Toorn's threefold classification of the history of religion. See also Miller, 'Israelite Religion', 201-211 for a survey and evaluation of the history of religion. 
1744) and Johann Gottfried Herder (1744-1803) who identified the 'populari' and 'Volk' as a foundation for a new humanism apart from the rationalising discourse of the Enlightenment ${ }^{12}$ even though Herder would denigrate Judaism when compared with Hebraism. However, it was only in the 1960-70s that the term 'popular religion', whether used positively or otherwise, began to emerge on its own merit in biblical research. Thus in 1963 Ringgren acknowledged that sizeable portions of the OT differed from the 'official' religion of their time in their perspective. ${ }^{13}$ In 1964-65 C.J. Labuschagne deplored popular religion as a 'corruption and perversion of true Yahwism, imperceptibly moving with the prevailing spirit of the times, like a putrefaction transmuting one living cell after the other.' ${ }^{14}$ Obviously he was unable to identify early Yahwism itself as a 'popular' religion. This was the time, however, when both Vriezen ${ }^{15}$ and Crenshaw ${ }^{16}$ were calling for turning the spotlight onto the 'man in the streets'. As recently as 1983 Schmidt admitted the possibility of popular piety but did not consider it worthy of inclusion. ${ }^{17}$ In the same year Ahlström entertained the possibility of such a phenomenon in the context of his discussion on national religion in Israel. ${ }^{18}$

Meanwhile, the study of Israelite religion continued alongside the growing smorgasbord of newer disciplines in the area of OT studies. A significant contribution was made by Albertz's two-volume $A$ History of Israelite Religion in the Old Testament Period (ET 1994) which attempts to address the issue of 'popular piety'. Albertz recognised that "the exclusion of "popular piety" limits the whole approach once again to a line conceived of in ideal terms, and hardly allows any dispute over the understanding of God.' 19 Though Albertz offers seven suggestions for a manifesto of the study of Israelite

\footnotetext{
12 Charles H. Long, 'Popular Religion', in The Encyclopaedia of Religion, ed. Mircea Eliade (New York: Macmillan, 1987) 443.

13 H. Ringgren, Israelite Religion (ET D.E. Green; London: SPCK, 1966) 248.

14 C.J. Labuschagne, 'Amos' Conception of God and the Popular Theology of His Time', in Papers Read at 7th and 8th Meetings of Die O.T. Werkgemeenskap in Suid-Afrika (1964-1965) 123.

15 T. Vriezen, The Religion of Ancient Israel (ET H. Hoskins; Philadelphia: Westminister, 1967) 20.

16 James L. Crenshaw, 'Popular Questioning of the Justice of God in Ancient Israel', $Z A W 82$ (1970) 392.

17 W.H. Schmidt, The Faith of the Old Testament: A History (ET John Sturdy; Oxford: Blackwell, 1983) 9.

18 G.W. Ahlström, Royal Administration and National Religion in the Old Testament (Leiden: E.J. Brill, 1982) 26.

19 Albertz, History of Israelite Religion, 10.
} 
religion ${ }^{20}$ in which he calls for dialogue with comparative religion and discusses 'two foci of identity' - the family and the people ${ }^{21}$ - and also discusses personal piety and syncretism, he deems the category of 'popular religion' to be inadequate ${ }^{22}$ and does not include a dialogue with such religions in his manifesto. ${ }^{23}$

What really gave popular religion a much-needed push in the arena of biblical studies was burgeoning interest in and proliferation of publications on the subject in non-biblical research ${ }^{24}$ and the flood of archaeological discoveries in biblical research. ${ }^{25}$ Thus Holladay could propose his hypothesis of 'tolerated non-conformist worship' and cite evidence of locations pertaining to such worship on the basis of archaeological findings. ${ }^{26}$ Dever collated archaeological evidence concerning unauthorised priests, bamot and massebot, the Asherah cult, altars, incense offerings, horse-and-chariot imagery, temple prostitution, child sacrifice, magic, tombs and burial practices and concluded that popular religion was practised within the Jerusalem Temple, the immediate vicinity of the Temple and elsewhere in Jerusalem; and the countryside. ${ }^{27}$ The Medellin (1968) and Peubla

\footnotetext{
20 Albertz, History of Israelite Religion, 12.

21 Albertz, History of Israelite Religion, 19. These foci will be discussed later on in the paper.

22 Albertz, History of Israelite Religion, 18.

23 Albertz, History of Israelite Religion, 19, does identify a third level of the 'village community' between the levels of family and the people. In proposing the category of the family in relation to 'personal piety', he rightly affirms that there was 'no such thing as the individual detached from the family'. However, he forgets that there was no such thing as the family detached from the clan, and the clan detached from the tribe! The whole threefold scheme is too readily assumed and not problematised enough.

24 Cf. Berlinerblau, 'Popular Religion', and Jacques Berlinerblau, The Vow and the 'Popular Religious Groups' of Ancient Israel: A Philological and Sociological Inquiry (JSOTSS 210; Sheffield: Sheffield Academic Press, 1996) 17-28. M. Daniel Carroll R., ed., Rethinking Contexts, Rereading Texts: Contributions from the Social Sciences to Biblical Interpretation (JSOTSS 299; Sheffield: Sheffield Academic Press, 2000) for methodological impetus from non-biblical research. See also fn. 2 for non-biblical studies in popular religion.

25 Ahlström, 'Royal Administration', 82.

26 John S. Holladay, 'Religion in Israel and Judah under the Monarchy: An Explicitly Archaelogical Approach', in Ancient Israelite Religion: Essays in Honor of Frank Moore Cross, ed. P.D. Hanson, P.D. Miller, S. Dean McBride (Philadelphia: Fortress, 1987) 269.

27 William G. Dever, 'The Silence of the Text: An Archaeological Commentary on 2 Kings 23: The Contribution of Archaeology to the Study of Canaanite and Early Israelite Religion', in Scripture and Other Artifacts: Essays on the Bible and Archaeology in Honor of Philip J. King, ed. M.D. Coogan, C.J. Exum, and L.E. Stager (Louisville, KY: Westminster John Knox, 1994) 146-58.
} 
(1978) conferences in Latin America, 28 the fascination with spirit, ancestor and tribal religions in Africa, ${ }^{29}$ the rise of subaltern ${ }^{30}$ and Dalit movements in India ${ }^{31}$ and even voices from the feminist and aboriginal movements in the Western world drew attention to the issue of deriving social meaning from levels other than the establishment or the elite classes of society. Attempts to define, rechristen or even reject popular religion catapulted the discipline to popularity. ${ }^{32}$ While Peter Williams felt that "wpopular religion" is too useful as an heuristic, if not a classificatory, device to be done away with,' Towler regards the term 'popular religion' as 'too vague to signify anything at all'. ${ }^{33}$ Some biblical scholars, too, continued to display scepticism. Tigay's conclusion from his examination of onomastic and epigraphic evidence that from the monarchy onwards, perhaps even earlier, Israelites did not worship other gods besides Yahweh, rules out the existence of popular religion ${ }^{34}$ (if one does indeed uncritically understand popular religion as the worship of nonIsraelite gods, as many scholars do!). ${ }^{35}$

Berlinerblau considers Vrijhof and Waardenburg's Official and Popular Religion: Analysis of a Theme for Religious Studies to be the groundbreaking volume in the discussion. ${ }^{36} \mathrm{He}$ notes: 'Since the publication of this work little has been said about the official dimensions of religion. It would seem that many scholars are atoning for years of neglect by focusing exclusively on the issue of "popular religion".'37 Berlinerblau himself has been at the forefront of deliberations with substantial proposals offered for definition,

\footnotetext{
28 L. Maldonado, 'Popular Religion: Its Dimensions, Levels and Types', Concilium (1986) 3. Concilium devoted an entire issue to Popular Religion in 1986.

29 Sidbe Semporé, 'Popular Religion in Africa: Benin as a Typical Instance', Concilium 186 (1986) 44-51.

30 Ranajit Guha, ed., Subaltern Studies: Writings on South Asian History and Society, vols. 1-6 (Delhi: OUP, 1986-1992), Partha Chatterjee \& Gyanendra Pandey, eds., Subaltern Studies: Writings on South Asian History and Society, vol. 7 (Oxford: OUP, 1993).

31 Sathianathan Clarke, Dalits and Christianity: Subaltern Religion and Liberation Theology in India (Delhi, Oxford: OUP, 1998).

32 For details see Berlinerblau, 'Popular Religion', 5.

33 Cited in Berlinerblau, 'Popular Religion', 6.

34 Jeffrey H. Tigay, 'Israelite Religion: The Onomastic and Epigraphic Evidence', in Ancient Israelite Religion, ed. P.D. Hanson, et al., 180.

35 Berlinerblau, 'Popular Religion', 4.

36 Vrijhof \& Waardenburg, Official and Popular Religion.

37 Berlinerblau, The Vow, 23.
} 
nomenclature and methodology. ${ }^{38}$ More recently, there have been at least four foci of interest that have surfaced in what could be generically termed as popular religion. These are (1) family religion; (2) the cult of the goddess; (3) religious iconography and the rise of aniconism; and (4) the continuity between Israelite and Canaanite religion. ${ }^{39}$ The specific treatments of certain narratives or personages as representative of popular religion have been the most current developments, with Thomas W. Overholt considering Elijah and Elisha in the context of popular religion ${ }^{40}$ and Daniel Carroll using theory from the ancillary discipline of interpretative anthropology to do the same with Amos. ${ }^{41}$

\section{The Problem of Definition}

Berlinerblau identifies three significant works in the last century which discuss popular religion; viz. Eduard Meyer's chapter 'Die judische Volksreligion in Jerusalem und in Elephantine' (1912), Anton Jirku's Materialien zur Volksreligion Israels (1914) and Yehezkel Kaufmann's 'The Religion of the People' in his The Religion of Israel: From Its Beginnings to the Babylonian Exile (1953).42 In addition to these he mentions a spurt of writings on popular religion in the 70's and 80's. However, he rightly points out that all the above scholars have been reluctant to offer 'any theoretical analysis, precise definitions or even conscious consideration of the term'. The impression given is that a tacit consensus already exists about the precise meaning of the term 'popular religion', he says. ${ }^{43}$ As recently as 1996, he lamented that 'popular religion' was a 'crucial' but 'irritatingly multivalent term' that earlier scholars have refrained from discussing or defining. ${ }^{44}$ Earlier, in 1963 Ahlström had already

\footnotetext{
38 Berlinerblau The Vow, 'Popular Religion'.

39 Van der Toorn, 'Israelite Religion', 13.

40 T.W. Overholt, 'Elijah and Elisha in the Context of Israelite Religion', in Prophets and Paradigms: Essays in Honor of Gene M. Tucker, ed. Stephen Breck Reid (Sheffield: Sheffield Academic Press, 1996).

41 M. Daniel Carroll R., “For so you love to do": Probing Popular Religion', in Carroll R., ed., Rethinking Contexts, Rereading Texts.

42 Berlinerblau, 'Popular Religion', 5.

43 Berlinerblau, 'Popular Religion', 5.

44 Berlinerblau, The Vow, 14. He uses the term fenced in by single quotes throughout his work. He adds: 'While there may be some theoretical similarities among the approaches of researchers who engage with this issue, there has not surfaced any recognized dominant paradigm or school to which the majority of
} 
pointed out that popular religion was 'a term often used but never defined with regard to content in the cultures of the Near East.' 45

While 'popular religion' has been used to mean: (a) the religion practised by the majority of the population, ${ }^{46}$ (b) the religion frequently practised, (c) the religion of marginalised groups, Berlinerblau points out that earlier exegetes have failed to clarify its connotations. ${ }^{47}$

A regrettable tendency has been to define popular religion by exclusion. Thus according to Susan Ackerman, popular religion 'is not the religion usually presented to us as normative in the Bible. More specifically, it is not the religion of the Deuteronomistic school, the priests, or the prophets, the three groups from whom the majority of our biblical texts come and the three groups who are most influential in defining what biblical religion is.' ${ }^{48}$ The problem with this assumption is that 'biblical religion' or Yahwism can in no sense be said to equal popular religion. Vorländer rather ambiguously defines it 'the popular ideas entertained by the Israelites concerning God's action in the life of the individual' 49 but tries to clarify it by exclusion. For him, those local rituals which 'were not part of the official, national religion, which was directed from the capital by the king's administration', constitute popular religion. ${ }^{50}$ For Vriezen, while a remnant remained faithful to Yahwism, 'the great mass of the people must undoubtedly have trimmed their sails to the wind.' 51 Again, T.J. Lewis defines popular religion within the context of his study of cults of the dead as 'a segment of society who were carrying out certain practices (death cult rituals) which were ultimately rejected

scholars pledge their allegiance. Consequently, numerous definitions of "popular religion" abound, but none has yet achieved hegemonic status' (idem, 'Popular Religion', 19).

45 G.W. Ahlström, Aspects of Syncretism in Israelite Religion (Lund: C.W.K. Gleerup, 1963) 26.

46 William G. Dever, 'The Contribution of Archaeology to the Study of Canaanite and Early Israelite Religion', in Early Israelite Religion: Essays in Honor of Frank Moore Cross, ed. P.D. Hanson, P.D. Miller, S. Dean McBride (Philadelphia: Fortress, 1987) 220.

47 Berlinerblau, The Vow, 14. See Berlinerblau 'Popular Religion' 6, fn. 7 for a list of those who propose various approaches as well as those who deal with difficulties inherent in defining this term.

48 Susan Ackerman, Under Every Green Tree: Popular Religion in Sixth-Century Judah (HSM46; Atlanta: Scholars, 1992) 1.

49 Vorländer, 'Popular Religion', 63.

50 Vorländer, 'Popular Religion', 26. Nevertheless, he does admit that there must have been mutual influencing and resemblances between the two.

51 Vriezen, Religion of Ancient Israel, 20. 
by the Yahwism which became normative.' 52 Even Berlinerblau falls prey to the supposition that popular religion has to be non-Israelite or non-Yahwistic. He suggests retaining the term 'popular religion' only as a 'disciplinary logo' 53 while preferring to identify 'popular religious groups' which he defines as 'any association of individuals living within the borders of ancient Israel who by dint of their religious beliefs, political beliefs, rituals, symbols and so on, are denigrated by the authors of the Old Testament. ${ }^{54}$ While his effort to avoid generalisations is commendable, his view that such groups are the creation of the biblical authors ${ }^{55}$ robs them of their potential to carve a niche for themselves on the pages of biblical history. Moreover, seen from the perspective of interpretive anthropology, Daniel Carroll would maintain that "popular religion" would refer to the religion of the general population and would not be limited to certain sub-groups.' ${ }^{56}$ One of the most comprehensive definitions of popular religion is that of Dever, whose only problem seems to be the over-emphasis of the individualistic nature of popular religion in a society that was so communally oriented. He describes popular religion as:

....an alternate, nonorthodox, nonconformist mode of religious expression. It is noninstitutional, lying outside priestly control or state sponsorship. Because it is nonauthoritarian, popular religion is inclusive rather that exclusive; it appeals especially to minorities and to the disenfranchised (in the case of ancient Israel, most women); in both belief and practice it tends to be eclectic and syncretistic. Popular religion focuses more on individual piety and informal practice than on elaborate public ritual, more on cult than on intellectual formulations (i.e., theology). By definition, popular religion is less literate (not by that token any less complex or sophisticated) and thus may be inclined to leave behind more traces in the archaeological record than in the literary record, more ostraca and graffiti than classical texts, more cult and other symbolic paraphernalia than scripture. Nevertheless, despite these apparent dichotomies, popular religion overlaps significantly with official religion, if only by sheer force of numbers of practitioners; it often sees itself as equally legitimate; and it attempts to secure the same benefits as all religion, namely the individual's sense of integration with nature and society, of health and prosperity, of ultimate well-being. 57

52 T.J. Lewis, Cults of the Dead in Ancient Israel and Ugarit (HSM 39; Atlanta: Scholars, 1989) 2.

53 Berlinerblau, 'Popular Religion', 19.

54 Berlinerblau, 'Popular Religion', 18.

55 Berlinerblau, 'Popular Religion', 18.

56 M. Daniel Carroll R., 'Re-examining "Popular Religion": Issues of Definition and Sources. Insights from Interpretive Anthropology', in Carroll R., ed., Rethinking Contexts, Rereading Texts, 156.

57 Dever, 'Silence of the Text', 160. 
Currently though, in a postmodern setting, "the desire to achieve the universal, ahistorical definition of "popular religion" remains "very weak', says Berlinerblau, with scholars settling for 'local definitions ... constructed to conform to the unique circumstances encountered in the particular society' being studied by the researcher. ${ }^{58}$ One of the tasks of this paper will be to propose a definition of popular religion after perusing some of its characteristics and examining it vis-à-vis its counterpart 'official religion', for as Berlinerblau rightly opines, 'the definition of "popular religion" is inextricably intertwined to that of "official religion".,59

\section{Popular Religion and Official Religion}

The study of popular religion in isolation from its counterpart, has been one of its biggest lacunae in biblical studies. Berlinerblau admits "the possibility that "official" and "popular" religion exerted a reciprocal influence upon one another is only rarely addressed.' 60 On the other hand, the dialectical character of this relationship has been the subject of much discussion in non-biblical research. ${ }^{61}$

Badone suggests that 'it is more fruitful to focus on the dialectical nature of their interrelationship'. ${ }^{62}$ After all, Israelite religion has been studied using the dialectics of Hegel, the dialectics between political and religious history, ${ }^{63}$ and the dialectics between Israel's religion and that of her neighbours.

It is true that the study of such a dialectic between official and popular religion as the driving force behind its development is sure to reveal previously unknown avenues. After all, 'it constitutes one of the most widespread and consistent findings in modern "popular religion" research.' 64 One of the directions further research could take would be to demonstrate how this reciprocity is at its peak during the monarchy and to identify and discuss texts, events, a period or a

58 Berlinerblau, The Vow, 20.

59 Berlinerblau, The Vow, 15.

60 Berlinerblau, The Vow, 8.

61 See Berlinerblau, 'Popular Religion' for details.

62 E. Badone, 'Introduction', in Religious Orthodoxy and Popular Faith in European Society (Princeton, NJ: Princeton University Press, 1990) 6.

63 R. Smend, Lehrbuch, 7.

64 Berlinerblau, 'Popular Religion', 9. In fn. 17 he lists works in non-biblical research that discuss such a dialectic. He concludes from these studies that a 'nexus' must exist among the various religious groups in a society. 
paradigm where this reciprocity is most clearly seen. This would enable one to study further the dynamics of such a relationship.

Berlinerblau highlights three hallmarks of official religion: (1) It is constituted by those belonging to an economically privileged class and thus is ideologically used to legitimise class domination. This assumption is open to criticism in the light of the 8th century prophetic texts that associate the wealthy exploiters with popular religions (that is, if one understand 'popular religion' as nonYahwistic). (2) It tends to rationalise and systematise which gives rise to an elite class of specialists. (3) It is 'administered, managed and controlled' almost entirely by men. ${ }^{65}$ One exception, which perhaps proves the rule, is Queen Jezebel who is chief promoter of the Baal cult. Here again, one would have to ask whether the Baal cult was 'popular' or 'national', and if the latter is true, the definition of 'popular religion' as heterodoxy is proved to be limited.

Thus an official religion is one that 'is capable of carrying out its own will against other religious groups', by creating a 'dominant conception of social reality'. As Berlinerblau succinctly puts it: 'the sine qua non of "official religion" lies in its ability to make its particular theological agenda assume the status of "orthodoxy" within a given territory.' 66 However, if as Berlinerblau opines: orthodox is 'official' and heterodox is 'popular' 67 - what happens when those in power (the officials) subvert what was once orthodox Yahwism and turn it into syncretistic heterodoxy? This happens frequently during the monarchy, e.g. the persecution of Elijah by Ahab and Jezebel. Further, is it not possible for orthodox official religion to be infiltrated by heterodoxy?

A rigid demarcation that views official or popular religion as monolithic entities is hence neither possible nor desirable. ${ }^{6}$ 'Beliefs and rituals which are a part of the religion of the king may just as easily be "popular" as those which belong to the cult of the commoner; similarly the temple may as likely contain "popular" religion as the high places of the bamot,' says Ackerman. ${ }^{69}$ Vrijhof and Waardenburg rightly observe: 'Both the terms official religion

65 Berlinerblau, The Vow, 25-27.

66 Berlinerblau, The Vow, 27.

67 Cf. n. 51.

68 For discussion on this and citations by others see Berlinerblau, The Vow, 22.

69 Ackerman, Under Every Green Tree, 1. 
and non-official religion must not be regarded as static, substantial concepts indicating fixed, separate entities. ${ }^{70}$

\section{Characteristics of Popular Religion}

There is a certain consensus as far as features of popular religion are concerned, especially in non-biblical research. The following characteristics may be pointed out:

- It concerns demographically small groups. ${ }^{71}$ However, there may be cases when such diverse groups come together and constitute a people or a nation on the basis of their popular belief, as did the Israelites after liberation from Egypt, according to some sociological models. Segal thinks that popular religion is individualistic rather than corporate-cultic without giving enough reason for his claim. ${ }^{72}$

- It concerns groups that may be economically, ethnically, socially, culturally or cultically marginalised. Such groups may not be foreigners but "pose the problem of "otherness" for people outside their communities ... They are nevertheless integrated into the social structure as a necessary ingredient of a common cultural ideology and its functioning. ${ }^{73}$ Such groups need not be syncretistic and devotees of non-Israelite gods (heterodox) as Ackerman and others seem to think. They may also be constituted by the 'orthodox', e.g. prophetic communities (1 Ki. 19:18, 1 Sa. 10:10). It would need to be determined in the course of the discussion if 'popular' implies common, meaning that which is practised by a greater number of people, or implies that which is practised by the lower strata of people - the common people and not the elite?

- Women play an important role (they constitute one of the groups who are marginalised from official religion). ${ }^{74}$ However, they were closely linked with magic in Israel and elsewhere in the ANE. ${ }^{75}$ The medium at En-dor (1 Sa. 28:7) is a good example. Carol Meyers and Phyllis Bird have undertaken pioneering

70 Berlinerblau, The Vow, 23.

71 Long, 'Popular Religion', 443.

72 J.B. Segal, 'Popular Religion in Ancient Israel', JJS 27 (1976) 2.

73 Long, 'Popular Religion', 446.

74 Berlinerblau, The Vow, 27.

75 Segal, 'Popular Religion', 5-6. 
research into the role of women in popular religion. Meyers analyses the household mode of production, together with archaeological findings in domestic locales to explore the part women played in household religion. ${ }^{76}$ Bird concentrates on local shrines, pilgrimages, and individual acts of devotion related to particular needs that would fit in better with the lives and needs of women. ${ }^{77}$

- Itinerant 'men of God' also play a considerable role. Most striking is the bond between them and Israelite women. The man of God had special concern for the sick, was not afraid of ritual uncleanness that would have put off clerics of official religion, says Segal. 78

- There is shared space and a continuum between the sacred and profane, the moral and the religious. ${ }^{79}$

- It is dominated by oral tradition as it has no access to sacred texts which are monopolised by official religion.

- It has high regard for the symbolic and the imaginative and is hence associated with images. 80

- It is the religion of rural, folk and peasant cultures that revolves around agrarian life and carves out an 'ecological niche' for itself. ${ }^{81}$ It may hence be nature-based and animistic. It may arise from isolated events that do not fit into the cycle of an annual calendar, i.e. building of a house, planting of a vineyard, natural disasters, but above all, marriage, birth and death that the devotee attempts to control by means of magic. 82

- It is practised by the laity in a religious community in contrast to that of the clergy. 83

- It is pervaded by esoteric forms of healing and therapeutic practices, foretelling that is not based on rational deduction, and

76 C.L. Meyers, Discovering Eve: Ancient Israelite Women in Context (Oxford: OUP, 1988); idem, 'Of Drums and Damsels: Women's Performance in Ancient Israel', Biblical Archaeologist 54 (1991).

77 Phyllis Bird, 'Israelite Religion and the Faith of Israel's Daughters: Reflections on Gender and Religious Definition', in The Bible and the Politics of Exegesis, ed. David Jobling, Peggy Day and Gerald Sheppard (Cleveland, Ohio: Pilgrim, 1991).

78 Segal, 'Popular Religion, 9.

79 Long, 'Popular Religion', 443.

80 Maldonado, 'Popular Religion', 7.

81 Long, 'Popular Religion', 444.

82 Segal, 'Popular Religion', 2. Also pervaded by dreams and the Urim and the prophets that Saul consulted openly (1 Sa. 28:6, later Je. 14:14, 23:25-28., 27:9 etc).

83 Long, 'Popular Religion', 445. 
a different cosmology from the one prevalent within the society as a whole. 84

- It is dominated by the magical element and by intuitive behaviour. 85

- It is permeated by the mystical. ${ }^{86}$

- It is distinguished by the festive and the theatrical. ${ }^{87}$

- It is the religion of the masses as opposed to the religion of the 'sophisticated, discriminating and learned within a society'. 88

- $\quad$ Ringgren sees popular religion as syncretistic, ${ }^{89}$ Lang sees it as polytheistic 90 existing alongside the official religion of the temple, prophetic religion and Deuteronomic religion; the result of Israelite borrowing from the Canaanite religion into whose land they had entered. ${ }^{91}$ There are, however, two difficulties with this view. First, official religion itself may have been even more syncretistic or polytheistic (as promoted by Ahab and Jezebel) while non- or anti-syncretistic prophetic religion may have been more 'popular' during certain periods. Secondly, when Israel borrowed practices of Canaanite worship, it may have been that she popularised what was once the official religion of Canaan. Ringgren's view does not allow for the possibility that what was official to one may have become popular to the other.

- Maldonado also mentions the 'political' as a legitimate dimension of popular religion since it has 'often contributed to the preservation of a people's self-awareness and has sometimes led to a struggle for dignity, emancipation and liberty'.92

\section{Sources and Method}

The study of popular religion is exciting because one is looking for buried treasure, a subterranean and a subaltern world. Most sources

\footnotetext{
84 Long, 'Popular Religion', 446.

85 Maldonado, 'Popular Religion', 7.

86 Maldonado, 'Popular Religion', 7.

87 Maldonado, 'Popular Religion', 7.

88 Long, 'Popular Religion', 446.

89 Ringgren, Israelite Religion, 58. See also Ahlström, Aspects of Syncretism, 11.

90 B. Lang, Monotheism and the Prophetic Minority: An Essay in Biblical History in Sociology, vol. 1, (Sheffield: Almond, 1983) 20.

91 Ringgren, Israelite Religion, 96.

92 Maldonado, 'Popular Religion', 7.
} 
for grassroots history have only been recognised as sources because someone has asked a question and then prospected desperately around for some way — any way — of answering it (E.J. Hobsbawm). ${ }^{93}$ Hence, one does not expect 'official' or canonical sources to be explicit or even extensive in their documentation of popular religion. More importantly, given that the text is religious more than historical, the determining question is not that of the historicity of the documents, but if the texts are the products of a popular or elitist group of writers..$^{94}$ Ideology, not history, is at stake here.

Kaufmann rules out entirely the contribution of an elite in the writing of biblical material, concluding that biblical religion is 'not an esoteric religion of a spiritual elite like the higher pagan religions, but is a growth that is rooted in and nourished by the popular religion of Israel' ${ }^{95} \mathrm{At}$ the other extreme, Dever labels biblical texts 'elitist' and goes on to note that 'the Hebrew Bible is a highly sophisticated literary creation which was written by and for the intelligentsia, who preserved, transmitted, and finally edited it into its final form'. ${ }^{96}$ The question that must be asked here, is that of literary standards. Is Dever applying modern standards of sophistication, or evaluating the texts according to the canons of their times? A more balanced position is that of Moshe Greenberg who sees the prayers in the scriptures as more reflective of popular supplication, while temple-ritual texts and Psalms come from the pen of experts. ${ }^{97}$ Dever goes on to propose a 'phenomenological or functionalist approach to religion and cult in ancient Israel, using archaeological data to illuminate the biblical texts. ${ }^{98} \mathrm{He}$ convincingly argues that a text-centred approach is not only elitist and plays into the ideological hands of the 'orthodox, nationalist, minority parties' but is also biased against ritual in the cult due to the sola scriptura perspective of many Protestant interpreters. 99

In the light of the above, Berlinerblau, presupposing that the texts are the handiwork of the elite or of royal patronage, regards them 'at

93 E.J. Hobsbawm, 'History from Below: Some Reflections', in F. Krantz (ed.), History from Below: Studies in Popular Protest and Popular Ideology (New York: Blackwell) 13-27.

94 Berlinerblau, 'Popular Religion', 10.

95 Y. Kaufmann, The Religion of Israel: From Its Beginnings to the Babylonian Exile (ET M. Greenberg; New York: Schocken Books, 1972) 132, 133.

96 William G. Dever, Recent Archaeological Discoveries and Biblical Research (Seattle, WA: University of Washington Press, 1990) 123.

97 Moshe Greenberg, Biblical Prose Prayer as a Window to the Popular Religion of Ancient Israel (Berkeley: University of California Press, 1983) 6-7.

98 Dever, 'Silence of the Text', 145-46.

99 Dever, 'Silence of the Text', 144-45. 
worst so thoroughly misrepresentative as to be of little value for the elucidation of popular religiosity'. ${ }^{100}$ This is his Achilles Heel as he assumes that the biblical authors were always on the side of the officials and fails to see them as subversive even in an official context. 'To what degree may valid historical information be extracted from a text whose authors were clearly beholden to a Yahwist "party line"?' he asks. ${ }^{101}$ The issue here is whether Yahwism, though being the national religion, was really an official (in the sense of establishment) or a popular religion? If the latter can be proved, then clearly the authors of scripture would have been sympathetic to popular religion and would have done their best to prevent the consolidation of an official or state religion.

$\mathrm{He}$ therefore delineates two concerns for students of popular religion. First, the biblical elitist writings may have been intentionally meant to misrepresent. Their agenda may have been to suppress voices deviating from monotheistic Yahwism. Thus a prima facie acceptance of them as Kaufmann, Vorlander and Segal have done is problematic. ${ }^{102}$ Secondly, the writers out of ignorance or out of an unconscious class bias may have unintentionally misrepresented the religiosity of other classes and groups. The question, then, is of the accessibility of material, reliable or otherwise to the student of popular religion. Berlinerblau comments: 'Herein lies one of the most disheartening verities of "popular religion" research. The student of "popular religion" probes in the interstices of history, and it is precisely these mundane quotidian activities and fleeting cognitions - not a register of great battles and royal coronations - which are of paramount importance.' 103

In the light of current hermeneutical discussions, no one would dispute the need to first problematise the sources themselves. However, Berlinerblau's pessimistic view is to be eschewed. It is itself ideologically loaded against the vox populi and does not take into consideration what Berlinerblau himself has suggested, viz. the 'nexus' between popular religion and official religion, which if it did exist would surely find its way into the text. I would like to suggest that even texts are written by a process of negotiation. Again, here a study of the dynamics between popular religion and official religion may throw light on the nature of the texts - are they elitist or

100 Berlinerblau, 'Popular Religion', 12.

101 Berlinerblau, 'Popular Religion', 16.

102 Berlinerblau, 'Popular Religion', 13.

103 Berlinerblau, 'Popular Religion', 15. 
otherwise? This will have to be answered after an examination of the texts themselves. The sui generis nature of portions of the biblical text must be kept in mind. As liberation theology has insisted the sui generis nature of portions of the biblical text is demonstrated by its penchant to retain the voices of the suppressed however muted and muffled. Thus the Deuteronomistic History could be seen as a result of the struggle between popular and official religion or a popular group taking over the official institution.

The above problems can be overcome by augmenting biblical material with extra-biblical archaeological and epigraphic data. There have been few takers like Dever and Holladay for this approach. This could possibly be a result of the disillusionment with the so-called Baltimore school of Albright, Bright and others who were alleged to have exaggerated archaeological evidence in favour of apologetic claims. Nevertheless, the wealth of material that has come to light fairly recently is overwhelming and has created new possibilities for the study of popular religion. One example of this is a comparative study of human and animal figurines found in Iron Age Palestine. Up to 1975, there was a far greater amount of figurines found in Jerusalem as compared to other sites [Jerusalem 597 figurines-149 were 'pillar' figurines, 199 horse and rider figurines, 258 animal figurines; Samaria 159 (39-25-21), Bethel 28 (7-2-10), Dan (1 pillar), Shechem 22 (4-1-3), Gibeon 64 (27-13-15), Hazor 44 (7-3-5)]. Ahlström views the figurines as 'popular religious phenomena that have no connection with the official religion of the nation' ${ }^{104}$ Despite this, he regrets the paucity of information on the official cult as well as on common practices, and pessimistically concludes that a "comparison of 'popular' religion and national religion is almost impossible.' 105 It is difficult to evaluate statistics such as these; but to find so many in the capital city suggests either that the figurines belong to official religion or that Jerusalem had a higher density of popular religion.

Another significant discovery are the inscriptions from Kuntillet Ajrud found about $50 \mathrm{~km}$ south of Kadesh Barnea. The findings have been tentatively dated between the middle of the ninth and the middle of the eighth centuries BC. A frequently repeated phrase from the inscriptions links Yahweh to his consort Asherah. 'It would not be surprising if Yahweh were thought to have a wife in some kinds of

104 Ahlström, Royal Administration, 83.

105 Ahlström, Royal Administration, 83. See also Tigay, 'Israelite Religion', who uses onomastic and epigraphic evidence. 
popular religion -or, indeed, in some forms of official religion,' says Emerton (italics mine). ${ }^{106}$ Dever affirms that '[A]rchaeology, with its focus on actual religious practice, offers an invaluable counterbalance to all idealistic systems that rob ancient Israelite religion of its diversity and vitality.' 107

The question of method is inseparably linked to the nature of the sources. Scholars who believed that the biblical texts are ideologically loaded, admit that they themselves come to the text with strongly ideological perspectives. Moreover, ancillary disciplines like sociology and anthropology are themselves enmeshed in methodological and ideological presuppositions. Hence, rather than venture into theoretical hot-spots of sociological or anthropological research, as Berlinerblau suggests 108 or into interpretive anthropology as suggested by Daniel Carroll, 109 it may be wise to proceed with a 'judicious analysis of literary material', 110 and refrain from abandoning exegetical methods before they are rigorously applied to the text and tested. This would also go hand in hand with a judicious handling of the archaeological evidence as Dever suggests. Thus 'by relating attested popular practices to various codes of law in the Bible, we may be able to trace the gradual incorporation of elements of popular religion into the established cult-or their rejection by the established cult.' 111

\section{Conclusion}

After scanning the past and surveying the present, directions for the future may be plotted out. It is first essential to map out formidable difficulties that lie ahead. Unlike living religions, there is no native informant available for consultation, only texts in classical languages. The sources may have been considerably reworked by functionaries

\footnotetext{
106 J.A. Emerton, 'New Light on Israelite Religion: The Implications of the Inscriptions from Kuntillet 'Ajrud', ZAW 94 (1982) 13.

107 Dever, 'Contribution of Archaeology', 236-37. See also 222-35 for his listing of recent discoveries and their usefulness for studying Israelite religion. Cf. Holladay, 'Religion in Israel and Judah', 249-99 for an explicitly archaeological approach to Israelite religion during the monarchy and especially his note 295, where he describes 'the officially sanctioned religious praxis' on the basis of archaeological evidence.

108 Berlinerblau, 'Popular Religion,' 3.

109 M. Daniel Carroll R., ed., Rethinking Contexts, Rereading Texts.

110 Segal, 'Popular Religion', 1.

111 Segal, 'Popular Religion', 1.
} 
of 'official' religion, in our case the Deuteronomists who came to the South and continued to maintain a theological bias in favour of the Jerusalem Temple. Application of the 'hermeneutic of suspicion' while not a finely honed and accurately developed tool would only lead to further ideological superimposition. Canonical criticism would show us that the imprimatur agencies responsible for putting together parts of the writings at various stages and confirming them, were 'official'. Thus, even though, for instance, the prophetic writings were composed against the official trends of their time (Je. 36), they would have later been accepted. What may have been the literature of opposition at the outset could become the commonly accepted doctrine in the course of time - and vice versa.

The term 'official religion' is crucial concerning the polytheistic religions of Israel's neighbouring nations. There are no vestiges of regulations regarding regional, social or even personal worship and beliefs, for instance, in Ancient Egypt (except for the period of Akhenaton). The kings had their dynastic deities, participation in the cult was restricted, nevertheless these deities were revered by the populace. On the other hand, the king contributed to numerous sanctuaries within the country, which were not relevant for the functioning of the government.

The biggest difficulty lies in discerning official and popular voices in the pre-stages of the canon. Is Jeroboam's cult official or popular? When the cult sponsored by the kings in the North become syncretistic and 'popular' do they not continue to be 'official'? Was the Yahwism of the South or the North 'official'? If so, in what sense? No doubt, people in the rural areas may have practised a rather primitive form of Yahwism, restricted to the welfare of the clan and the fertility of flocks and soil. But how does one arrive at a fairly accurate reconstruction of such a religion? The polemics of the prophets present us with only indirect hints. Archaeology may be able to shed some light, but nearly all documents and seals and probably many of the figurines (except for artefacts belonging to "hearth and home') are likely to have belonged to the privileged class. The analysis of personal names would again yield only limited information with regard to religious practices and in any case many of them are Yahwistic.

There are problems with Albertz's reconstruction of Israelite religion. Many of his arguments are based on dubious grounds. Albertz goes to the texts with his sociological theory fixed. Van der Toorn, on the other hand, treats Israelite religion under the category of 
family religion covering extensive ground and comparing it with other ANE religions. Even Vrijhof and Waardenburg conclude indecisively and are not sure whether to continue using the categories of popular and official religion. From the articles in their book it becomes clear that such categories are useful only in the case of living religions that have a fixed doctrinal and dogmatic pattern like Islam or Roman Catholicism (even in the case of the latter, official and popular religion sometimes overlap).

Despite the above difficulties, there is considerable pressure on OT scholars to continue to struggle with the issue of popular religion. At least seven suggestions may be offered. First and foremost, history of Israelite religion will have to take popular religion more and more seriously, while remaining cautious of the philosophical presuppositions that earlier kept the study of popular religion at bay. Secondly, despite the postmodern reluctance to assign universal definitions to local constructs, the universal nature of popular religion, keeping in mind its local variants, calls for a consensus on a working definition of popular religion on the part of biblical scholars. Thirdly, a method that dovetails the biblical evidence with archaeological findings would provide valuable clues to the nature of popular religion in the biblical period. This would have to go hand in hand with methods that help discern the ideological import of the sources. Fourthly, popular religious groups are to be studied not in isolation, but with a view to identify commonalties, affinities as well as radical differences. Fifthly, the position that equates heterodoxy with popular religion needs to be challenged and more attention paid to Yahwism as a popular religion. Sixthly, the role of prophets in popular and official religion, particularly the pre-classical prophets needs attention. In the same vein, one would also need to understand the role played by women. Seventhly, the nature of popular religion as oppressive and liberating would have to be explored. Finally, and most importantly, the dialectic between popular and official religion - the confluence, collaboration and conflicts between the two needs examination. Four levels of religion may be suggested: popular Yahwism, state-sponsored Yahwism, popular Near Eastern religions, and national Near Eastern religions. 